\title{
Overview of Common Regimens Used for Initiating and Titrating Insulin in Individuals with Type 2 Diabetes Mellitus
}

Joan S Grant ${ }^{\star}$, Mary Annette Hess and Laura A Steadman

University of Alabama at Birmingham, Birmingham, USA

"Corresponding author: Joan S Grant, University of Alabama at Birmingham, Birmingham, USA, Tel : E-mail : grantj@uab.edu

Received date: September 30, 2014, Accepted date: January 09, 2015, Published date: January 14, 2015

Copyright: (C) 2015 Grant JS et al. This is an open-access article distributed under the terms of the Creative Commons Attribution License, which permits unrestricted use, distribution, and reproduction in any medium, provided the original author and source are credited.

\begin{abstract}
The prevalence of Type 2 diabetes mellitus has dramatically increased and patients may require insulin therapy to effectively manage their diabetes mellitus. Nurses and other health professionals can assist these individuals to be more confident as they initiate and continue insulin therapy. This article discusses barriers to initiating insulin, target glycemic goals, and common regimens used for initiating and titrating insulin in individuals with T2DM. Implications for health professionals are addressed. Literature was reviewed using key words for regimens used for initiating and titrating insulin in individuals with type 2 diabetes mellitus and limited to those published in English from January 2007 to December 2014, unless earlier data were cited in papers as a primary source. Many reviewed sources cited information derived from the American Association of Clinical Endocrinologists/American College of Endocrinology (AACE/ACE) and the American Diabetes Association/European Association for the Study of Diabetes (ADA/EASD). Common insulin regimens use basal insulin only and basal insulin plus a rapid-acting insulin to one or more meals. Health clinician, health system, and patient barriers influence initiating and titrating insulin therapy to achieve target goals consistent with a $\mathrm{HbA} 1 \mathrm{C}$ of $<7.0 \%$, except in patients with multiple co-morbidities or severe hypoglycemia. Health professionals must work together to assess patient characteristics; determine target glucose goals; use strategies to address heath clinician, health system, and patient barriers; and initiate and titrate insulin therapy.
\end{abstract}

Keywords: Insulin; Diabetes mellitus; Clinical endocrinologists; Hemoglobin

\section{Overview of Common Regimens Used forInitiating and Titrating Insulin in Individuals with Type 2 Diabetes Mellitus}

Diabetes mellitus is a chronic disease that affects more than 25 million children and adults in the United States, with Type 2 (T2DM; Table 1) accounting for the majority of these cases [1]. While empirical evidence strongly supports the importance of anti-diabetes medications such as insulin therapy to achieve therapeutic glucose levels and lessen complications [2], only slightly over half of patients achieve target glycosylated hemoglobin (HbA1C) levels of $<7 \%$ [3]. Barriers to initiating and titrating insulin also influence the ability of patients to achieve target $\mathrm{HbAlC}$ goals [4]. In identifying practices of endocrinologists, family and nurse practitioners, diabetes educators, and other health care providers from a nationally representative, randomized sample regarding management of T2DM management, most health care providers lack confidence in using insulin regimens more complex than long-acting insulin alone [5].

\begin{tabular}{|l|l|}
\hline Abbreviation & Meaning of Abbreviation \\
\hline AACE/ACE & $\begin{array}{l}\text { Clinical Endocrinologists/American } \\
\text { College of Endocrinology }\end{array}$ \\
\hline ADA/EASD & $\begin{array}{l}\text { American Diabetes Association/ } \\
\text { European Association for the Study of } \\
\text { Diabetes }\end{array}$ \\
\hline DPP-4 & dipeptidyl peptidase 4 inhibitor \\
\hline
\end{tabular}

\begin{tabular}{|l|l|}
\hline FBG & fasting blood glucose \\
\hline GLP-1 & $\begin{array}{l}\text { glucagon-like peptide-1 receptor } \\
\text { agonist }\end{array}$ \\
\hline HbA1C & glycosylated hemoglobin \\
\hline IU & international unit(s) \\
\hline OADs & oral antidiabetes drugs \\
\hline SMBG & self-monitoring of blood glucose \\
\hline TZD & thiazolidinedione \\
\hline T2DM & Type 2 diabetes mellitus \\
\hline U & units \\
\hline
\end{tabular}

Table 1: List of Abbreviations.

Therefore, both patients and health providers must work together to address these barriers, achieve glycemic goals, and promptly initiate and titrate insulin therapy to better achieve glycemic goals and manage T2DM [6-8]. However, in reviewing published literature, most papers focus on one topic (e.g., barriers, initiating or titrating insulin therapy), rather than collectively discussing each of these factors important in achieving target glycemic goals in individuals with T2DM. Therefore, the purpose of this paper is to discuss barriers to initiating insulin, target glycemic goals, and common regimens used for initiating and titrating insulin in individuals with T2DM. Implications for health professionals are addressed. 
Citation: Grant JS, Hess A, Steadman LA (2015) Overview of Common Regimens Used for Initiating and Titrating Insulin in Individuals with Type 2 Diabetes Mellitus. J Nurs Care 4: 226. doi:10.4172/2167-1168.1000226

Page 2 of 9

\section{Barriers to Initiating and Titrating Insulin}

Empirical studies indicate overlapping obstacles occur from health clinicians, the health system, and patients/individuals with T2DM in initiating and titrating insulin (Table 2). A health clinician barrier is the intensive monitoring required to initiate and titrate insulin to assure patient safety. The time required to educate patients and their families about insulin therapy and important self-management skills is another significant health provider barrier. Further, a failure to set clear goals and consistently encourage patients and their families to meet target goals are other health clinician barriers [9].

\begin{tabular}{|c|c|c|}
\hline Type of Barrier & Barrier & Interventions \\
\hline \multirow[b]{2}{*}{ Health Clinician } & \multirow{2}{*}{$\begin{array}{l}\text { Intensive monitoring needed to safely initiate } \\
\text { and titrate insulin }\end{array}$} & $\begin{array}{l}\text { Encourage bidirectional patient and health team communication about } \\
\text { glycemic control. }\end{array}$ \\
\hline & & $\begin{array}{l}\text { Encourage patients to provide written and schematic evidence of } \\
\text { structured self-monitoring of blood glucoses with health providers at least } \\
\text { quarterly or more often. }\end{array}$ \\
\hline \multirow[t]{2}{*}{ Health Clinician } & \multirow{2}{*}{$\begin{array}{l}\text { Time required for adequate education of } \\
\text { patients and families about insulin therapy } \\
\text { and significant self-management skills }\end{array}$} & $\begin{array}{l}\text { Use adjunct methods to deliver information (e.g., telephone health lines, } \\
\text { telemedicine, web-based models, written information, audio- and video- } \\
\text { tapes. }\end{array}$ \\
\hline & & $\begin{array}{l}\text { Utilize checklists that highlight actual patient participation in diabetes self- } \\
\text { management skills. }\end{array}$ \\
\hline \multirow{3}{*}{ Health Clinician } & \multirow{3}{*}{$\begin{array}{l}\text { Failure to set clear goals and consistently } \\
\text { encourage patients and their families to meet } \\
\text { target goals }\end{array}$} & $\begin{array}{l}\text { Establish clear verbal and written goals at each patient and health } \\
\text { provider contact, encouraging patients and families to meet target goals. }\end{array}$ \\
\hline & & $\begin{array}{l}\text { Provide patient reminders that emphasize two to three short-term, } \\
\text { measurable self-management behaviors for patients to work toward before } \\
\text { next health provider contact. }\end{array}$ \\
\hline & & $\begin{array}{l}\text { Facilitate understanding of the meaning of serum lab values (e.g., } \mathrm{HbA} 1 \mathrm{C} \\
\text { and corresponding serum glucose levels) regarding the risk of potential } \\
\text { complications. }\end{array}$ \\
\hline \multirow{3}{*}{ Health System } & $\begin{array}{l}\text { Inadequate and inconsistent office visits to } \\
\text { discuss self-management skills }\end{array}$ & $\begin{array}{l}\text { Use adjunct methods to deliver information (e.g., telephone health lines, } \\
\text { telemedicine, web-based models, written information, audio- and video- } \\
\text { tapes. }\end{array}$ \\
\hline & $\begin{array}{l}\text { Inadequate interfaces between patients and } \\
\text { health professionals }\end{array}$ & $\begin{array}{l}\text { Use prerecorded telephone calls to patients, using an automated health } \\
\text { education or nurse telephone follow-up. }\end{array}$ \\
\hline & & $\begin{array}{l}\text { Identify and train community healthy advisors to offer useful strategies for } \\
\text { adapting lifestyles in living with T2DM. }\end{array}$ \\
\hline \multirow[t]{2}{*}{ Patient } & \multirow{2}{*}{$\begin{array}{l}\text { Feelings of personal failure in not } \\
\text { implementing healthier behaviors that would } \\
\text { prevent the need for insulin therapy }\end{array}$} & $\begin{array}{l}\text { Provide initial education, with reinforcement, that diabetes is progressive } \\
\text { and the need for additional agents, including insulin, may be required for } \\
\text { excellent control. }\end{array}$ \\
\hline & & $\begin{array}{l}\text { Encourage implementation of healthy behaviors, such as exercise and } \\
\text { eating benefcial foods that are low in fat, with controlled carbohydrates. }\end{array}$ \\
\hline \multirow[t]{2}{*}{ Patient } & \multirow{2}{*}{ Fear of taking insulin (injections) } & $\begin{array}{l}\text { Consider patient characteristics (dexterity, vision) and lifestyles in } \\
\text { selecting most appropriate method (e.g., finer insulin needles, pens, or } \\
\text { pump) for delivering insulin. }\end{array}$ \\
\hline & & $\begin{array}{l}\text { Discuss patient perceptions about taking insulin, emphasizing the value of } \\
\text { insulin in achieving target glucoses. }\end{array}$ \\
\hline \multirow{2}{*}{ Patient } & \multirow{2}{*}{$\begin{array}{l}\text { Fear of consequences of taking insulin (e.g., } \\
\text { hypoglycemia, weight gain) }\end{array}$} & Encourage daily testing, randomizing pre- and postprandial glucoses. \\
\hline & & Encourage daily exercise to lessen weight gain. \\
\hline \multirow{2}{*}{ Patient } & \multirow{2}{*}{$\begin{array}{l}\text { Insulin regimen signficantly interfers with } \\
\text { lifestyles }\end{array}$} & $\begin{array}{l}\text { Use motivational interviewing, support, and words of encouragement } \\
\text { regarding positive aspects of insulin therapy. }\end{array}$ \\
\hline & & $\begin{array}{l}\text { Discuss how insulin therapy allows patients to take control of their } \\
\text { diabetes. }\end{array}$ \\
\hline
\end{tabular}

Table 2: Barriers to Initiating and Titrating Insulin.

Health system barriers include brief office visits and inadequate interfaces between patients and other busy health professionals who support the success of initiating insulin in individuals with T2DM, such as physicians, nurses, diabetes educators, and dieticians [10]. In fact, Jones et al. [10] highlighted that office visits often were inadequate to review important diabetes self-management behaviors. 
Page 3 of 9

To illustrate, in office visits that ranged from 20 to 38 minutes, Kruse et al. [11] indicated health providers spent about 5 minutes with their patients discussing information such as medications, blood sugar testing and values, testing supplies, laboratory tests, vision, eye examinations, foot problems, diet, exercise, and smoking.

Individuals with T2DM also commonly perceive barriers in initiating insulin therapy. One significant barrier is a feeling of personal failure in not adequately adopting healthier behaviors that would prevent individuals with T2DM from requiring insulin [12,13]. However, many times this perception is untrue. Many patients require insulin therapy because of a decrease in beta cell function over time [13]. In fact, empirical research shows that the majority of individuals with T2DM will eventually require insulin therapy alone or in conjunction with oral antidiabetes drugs (OADs) to obtain or maintain optimal glycemic targets [14].

Other significant barriers for individuals with T2DM are a fear of needles/painful injections in taking insulin as well as a fear of potential consequences, such as hypoglycemia and weight gain. Another potential barrier is that insulin regimens significantly impact daily lifestyles [12,13]. About 7 to $15 \%$ of patients treated with insulin have at least one episode of hypoglycemia annually [15] while $7.3 \%$ experience severe hypoglycemia [16]. Some research literature suggests hypoglycemia in T2DM is underreported [15]. Further, in one study, $25 \%$ of patients reduced their insulin dose in response to a non-severe hypoglycemia [17] while almost $19 \%$ of individuals with T2DM reduced their insulin dose in response to nocturnal non-severe hypoglycemia [18]. Individuals who receive insulin also gain approximately 1-3 kilograms or between 2 to 7 pounds. Increasing rates of diabetes closely correlate with increasing rates of obesity [19]. Further, patients are less likely to adhere to insulin regimens the more they perceive those regimens are inconvenient regarding their lifestyle [13].

\section{Glycemic Goals and Need to Start Insulin}

In considering insulin as an option, glycemic goals must be considered for individuals with T2DM. In 2013, the American Association of Clinical Endocrinologists/American College of Endocrinology (AACE/ACE) recommend fasting and pre-meal blood glucoses of $<110 \mathrm{mg} / \mathrm{dl}$ without hypoglycemia for most patients with T2DM [19]. In contrast, the American Diabetes Association/European Association for the Study of Diabetes (ADA/EASD) recommend mean fasting glucoses of $<130 \mathrm{mg} / \mathrm{dl}$ and post-prandial glucoses of $<180$ $\mathrm{mg} / \mathrm{dl}[20]$ (Table 3).

\begin{tabular}{|l|l|l|}
\hline Recommendation & AACE/ACE & ADA/EASD \\
\hline \multirow{5}{*}{ Glucoses } & $\begin{array}{l}\text { Fasting and pre- } \\
\text { meal glucose of } \\
<110 \mathrm{mg} / \mathrm{dl} \text { without } \\
\text { hypoglycemia }\end{array}$ & $\begin{array}{l}\text { Fasting glucoses of } \\
130 \mathrm{mg} / \mathrm{dl} .\end{array}$ \\
\cline { 2 - 3 } HbA1C & $\begin{array}{l}\text { Post-prandial glucoses of } \\
<180 \mathrm{mg} / \mathrm{dl}\end{array}$ \\
\hline & $\begin{array}{l}\text { HbA1C } \leq 6.5 \% \\
\text { other of }>6.5 \% \text { for } \\
\text { factors (e.g., multiple } \\
\text { co-morbidities, } \\
\text { severe } \\
\text { hypoglycemia, etc.) }\end{array}$ & $\begin{array}{l}\text { HbA1C of } 6.0 \% \text { to } 6.5 \% \\
\text { for other conditions }(\mathrm{e.g} ., \\
\text { short disease duration, } \\
\text { no cardiovascul disease, } \\
\text { etc.) }\end{array}$ \\
\hline
\end{tabular}

\begin{tabular}{|l|l|l|}
\hline & & $\begin{array}{l}\text { HbA1C between 7.5\% to } \\
8.0 \% \text { for significant } \\
\text { characteristics similar to } \\
\text { those cited by } \\
\text { AACE/ACE }\end{array}$ \\
\hline \multirow{5}{*}{ Starting Insulin } & $\begin{array}{l}\text { HbA1C >9.0\% if } \\
\text { symptomatic }\end{array}$ & HbA1C $\geq 10 \%$ \\
\hline & $\begin{array}{l}\text { HbA1C >8.0\% if on } \\
\text { two or more OADs } \\
\text { or GLP-1 therapy } \\
\text { with long-stadning } \\
\text { T2DM }\end{array}$ & $\begin{array}{l}\text { HbA1C 9.0\%, if } \\
\text { considering ambination of three or } \\
\text { comb } \\
\text { more drugs }\end{array}$ \\
\hline
\end{tabular}

Table 3: Glycemic Goals and Starting Insulin.

The AACE/ACE recommend an $\mathrm{HbA1C}$ of $\leq 6.5 \%$ but allows customization for those with multiple co-morbidities, shorter life expectancies, a history of severe hypoglycemia or hypoglycemia unawareness, and other factors (e.g., cardiovascular and end-organ complications, motivation) [19]. The ADA/EASD recommend an $\mathrm{HbA} 1 \mathrm{C}$ of $<7 \%$ for the majority of patients but acknowledges that an $\mathrm{HbA1C}$ of 6.0 to $6.5 \%$ may be optimal for individuals with short disease duration, a longer life expectancy, and for those without cardiovascular disease [20]. Less stringent glycemic goals of an HbA1C between $7.5 \%$ and $8.0 \%$ may be appropriate for those patients with characteristics similar to those cited by AACE/ACE [21].

While the AACE/ACE and ADA/EASD differ regarding when it is best to start insulin, both groups highlight the importance of individualizing therapy based on patient preferences, schedules, concomitant illness, hypoglycemic awareness, and safety profile of glucose-lowering agents.For example, while the AACE/ACE suggest starting insulin with an $\mathrm{HbAlC}$ of $>9.0 \%$ and symptoms (e.g., weight loss, polyuria), insulin also may be used as one of the two drugs with dual therapy if glucoses are $\geq 7.5 \%$ after 3 months of monotherapy $[19,21]$. Further, this group of experts also recognizes individuals with T2DM who have an HbA1C of $>8.0 \%$, are on two or more OADs or GLP-1 therapy, and have long-standing T2DM are unlikely to reach target HbA1Cs with additional OADs [19].

In contrast, the $\mathrm{ADA} / \mathrm{EASD}$ propose starting insulin therapy with an $\mathrm{HbA1C}$ of $\geq 10 \%$ [21]. This group indicates insulin is more effective than most other agents (e.g., sulfonylurea, thiazolidinedione [TZD], dipeptidyl peptidase 4 inhibitor (DPP-4), and glucagon-like peptide-1 [GLP-1] receptor agonist) when considering a combination of three agents, particularly when HbA1Cs are at least 9.0\% [20]. Based on several randomized studies, HbA1c levels are safely lowered by $0.5 \%$ to $1.5 \%$ with monotherapy [22] as compared to $1.0 \%$ to $2.5 \%$ with insulin self-titration algorithms [12].

\section{Insulins}

Currently, there are more than 20 types of insulin on the market and several insulin regimens [12]. Insulin analogs have been modified chemically to either act faster or slower than insulin made naturally by the body. Therefore, analog insulins are modified to work more quickly to cover meals and lower post-prandial glucoses or to last longer to cover basal metabolism. Rapid-acting insulin analogs include lispro (Humalog ${ }^{\circledR}$ ), aspart (Novalog ${ }^{\circledR}$ ), and glulisine (Apidra ${ }^{\circledR}$ ). The onset, peak, and duration of rapid-acting analogs are less than 15 mins, 1 to 2 hrs., and 3 to 5 hrs., respectively [23]. NovoLog ${ }^{\oplus}$ Mix and Humalog Mix 75/25, 70/30, and 50/50 are examples of premixed 
insulin analogs that provide both an early and intermediate onset of action. Long-acting insulin analogs include glargine (Lantus ${ }^{\oplus}$ ) and detemir (Levemir $\left.{ }^{\circ}\right)$. The onset of long-acting insulins is $1 \mathrm{hr}$., they are mostly peakless, and the duration is up to $24 \mathrm{hrs}$ [23]. Because actions of analogs are more predictable, they typically are preferred over human (e.g., regular) insulin [24].

Premixed insulin provides less flexibility and has a higher incidence of hypoglycemia when compared to basal and basal bolus regimens. As a realistic compromise, the AACE/ACE recommended reserving premixed insulin for those who need a less complex regimen than that provided by a basal bolus treatment with long- and rapid-acting insulins [19]. Further, empirical data suggest basal long-acting insulin analogs such as glargine and detemir are preferred over intermediate acting insulins because of their relative flat effect for 24 hours, lessening the chance of hypoglycemia, and reducing HbAlCs from $1.5 \%$ to $1.8 \%$ from baseline $[19,25])$.
In comparing basal glargine and detemir insulin in four trials lasting 24 to 52 weeks and involving over 2000 individuals randomized to either insulin detemir or glargine, hypoglycemia and reductions in HbA1Cs were comparable. Detemir caused slightly less weight gain but patients required higher daily insulin doses. In contrast, glargine was injected once-daily with fewer injection site reactions [26].

\section{Initiating and Titrating Common Insulin Regimens}

Common insulin regimens use three regimens in initiating and titrating insulin in individuals with Type 2 diabetes mellitus. These consist of using 1) basal insulin only, 2) basal insulin in conjunction with prandial analog insulin before the largest meal of the day, and 3) basal insulin with a rapid-acting analog insulin before two or more meals (Table 4).

\begin{tabular}{|c|c|c|c|c|c|c|c|}
\hline Regimen & Insulin Name & Onset & Duration & Peak & Approach & HbA1c/ Glucoses & Dosage \\
\hline $\begin{array}{l}\text { Step 1: Add long-acting } \\
\text { basal insulin only }\end{array}$ & $\begin{array}{l}\text { glargine (Lantus) } \\
\text { detemir (Levemir) }\end{array}$ & $1 \mathrm{hr}$ & $\begin{array}{l}\text { Up to } 24 \\
\text { hrs }\end{array}$ & Mostly peakless & Fixed basal titration & $\begin{array}{l}\qquad 8.0-10 \% \\
\qquad 8.0 \% \\
\text { Titration of basal } \\
\text { insulin is primarily } \\
\text { based on fasting } \\
\text { glucose }\end{array}$ & 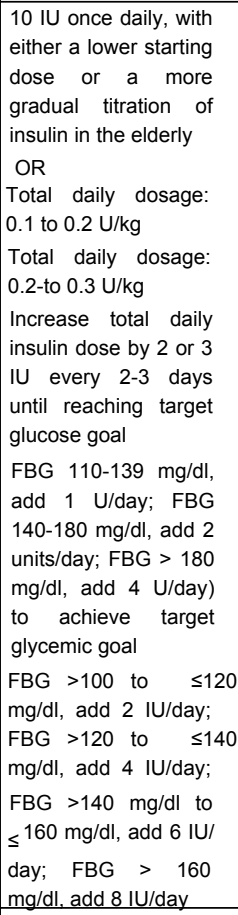 \\
\hline $\begin{array}{l}\text { Step 2: Add rapid acting } \\
\text { insulin injection before } \\
\text { largest or main meal of the } \\
\text { day (i.e., fairly consistent } \\
\text { meals) to basal insulin in } \\
\text { Step 1 }\end{array}$ & $\begin{array}{l}\text { Lispro (Humalog) } \\
\text { Aspart (novalog) } \\
\text { Glulisine (Apidra) } \\
\text { Plus } \\
\text { glargine (Lantus) } \\
\text { detemir (Levemir) }\end{array}$ & $\begin{array}{l}<15 \\
\operatorname{mins}\end{array}$ & $3-5 \mathrm{hrs}$ & $1-2 \mathrm{hrs}$ & $\begin{array}{l}\text { Initial dosage of rapid- } \\
\text { acting analog } \\
\text { Fixed titration of rapid- } \\
\text { acting analog } \\
\\
\text { Preprandial: } \\
\text { titration of rapid-acting } \\
\text { analog } \\
\text { Postprandial: adjustable } \\
\text { titration of rapid-acting } \\
\text { analog }\end{array}$ & $\begin{array}{l}\text { When } \mathrm{HbA} 1 \mathrm{C} \text { is } \\
\text { above target after } \\
3-6 \text { months of only } \\
\text { basal insulin }\end{array}$ & 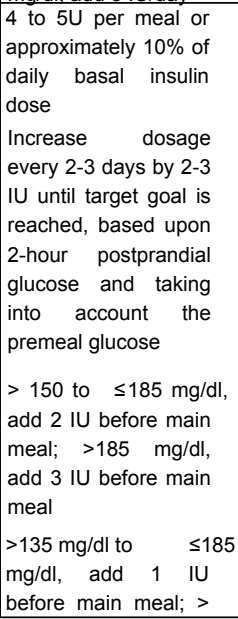 \\
\hline
\end{tabular}




\begin{tabular}{|c|c|c|c|c|c|c|}
\hline & & & & & & $\begin{array}{l}185 \mathrm{mg} / \mathrm{dl} \text {, add } 2 \mathrm{IU} \\
\text { before main meal }\end{array}$ \\
\hline $\begin{array}{l}\text { Step 3: Add rapid-acting } \\
\text { insulin prior to } 2 \text { or more } \\
\text { meals (e.g., if not achieving } \\
\text { target glucoses with Step } 2 \\
\text { regimen after } 3-6 \text { months or } \\
\text { with varying mealtimes and } \\
\text { carbohydrates) }\end{array}$ & $\begin{array}{l}\text { Lispro (Humalog) } \\
\text { Aspart (Novalog) } \\
\text { Glulisine (Apidra) } \\
\text { Plus } \\
\text { glargine (Lantus) } \\
\text { detemir (Levemir) }\end{array}$ & $\begin{array}{l}<15 \\
\text { mins }\end{array}$ & $3-5 \mathrm{hrs}$ & $1-2 \mathrm{hrs}$ & $\begin{array}{l}\text { Initial dosage of basal and } \\
\text { rapid-acting analog } \\
\text { Fixed titration of basal } \\
\text { dosage } \\
\begin{array}{l}\text { Adjustable titration of } \\
\text { basal dosage }\end{array} \\
\begin{array}{l}\text { Fixed titration of rapid- } \\
\text { acting analog }\end{array} \\
\begin{array}{l}\text { Adjustable titration of } \\
\text { rapid-acting analog with } \\
\text { varying carbohydrates }\end{array}\end{array}$ & 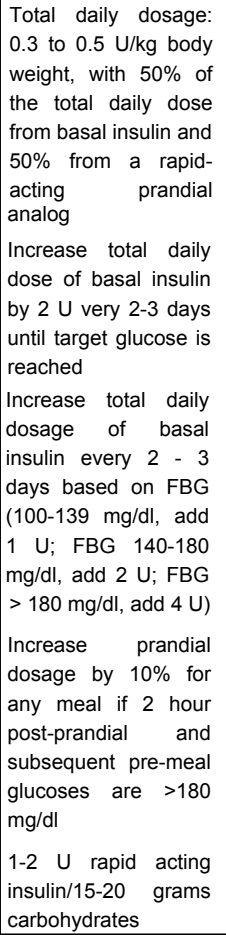 \\
\hline
\end{tabular}

Table 4: Approaches to initiating and titrating insulin in individuals with Type 2 diabetes mellitus.

\section{Step 1:}

Add Basal Insulin Only. Initially, insulin regimens commonly use OADs in conjunction with basal long-acting insulin only [19]. Regarding initial dosage, in the APOLLO trial using 377 patients, Bretzel et al. [27] suggests starting with a basal dose of 10 units once daily. Based upon a post-hoc analysis of elderly participants participating in a global, multiphase study comparing the efficacy, safety, and durability of two starter doses of insulin regimens, Wolffenbuttel et al. [28] recommend either a lower starting dose or a more gradual titration of insulin in the elderly because of safety risks associated with a potential alteration in glycemic thresholds for onset of hypoglycemia.

The AACE/AED suggest a starting dose of basal insulin of 0.1 to 0.2 units $/ \mathrm{kg}$ if $\mathrm{HbAlCs}$ are $\leq 8.0 \%$ and a dose of 0.2 to 0.3 units $/ \mathrm{kg}$ if HbA1Cs are between $8.0 \%$ and $10.0 \%$ [19]. The ADA/EASD has similar rates for initial basal dosages (e.g., 0.1-0.2 units/kg of body weight, with $0.3-0.4$ units $/ \mathrm{kg}$ of body weight for more severe hyperglycemia) $[20,21]$.

In titrating basal insulin, current approaches with fixed regimens commonly increase total daily doses of insulin by 2 [19] to 3 units, every two to three days until the desired glucose target is reached [12]. Insulin dosages are reduced by $20 \%$ for hypoglycemia (blood glucose $<70 \mathrm{mg} / \mathrm{dl}$ ) and by $40 \%$ for severe hypoglycemia (blood glucose $<40$ $\mathrm{mg} / \mathrm{dl}$ ). Health providers should consider discontinuing or reducing sulfonylureas after starting basal insulin [19].

In contrast to fixed regimens, adjustable regimens use fasting blood glucoses to titrate insulin doses every 2 to 3 days (i.e., fasting blood glucose [FBG] 110-139 mg/dl, add 1 unit/day; FBG 140-180 mg/dl, add 2 units/day; FBG $>180 \mathrm{mg} / \mathrm{dl}$, add 4 units/day) to achieve target glycemic goals [19]. Alternately, in monitoring FBG for 2 days with no significant hypoglycemia, Bretzel et al. [27] suggested a basal insulin titration algorithm of 2 international units (IU) of basal insulin for roughly every $20 \mathrm{mg} / \mathrm{dl}$ increase in glucoses above $100 \mathrm{mg} / \mathrm{dl}$ (i.e., FBG $>100$ to $\leq 120 \mathrm{mg} / \mathrm{dl}$, add $2 \mathrm{IU} /$ day; FBG $>120$ to $\leq 140 \mathrm{mg} / \mathrm{dl}$, add 4 IU/day; FBG $>140 \mathrm{mg} / \mathrm{dl}$ to $160 \mathrm{mg} / \mathrm{dl}$, add $6 \mathrm{IU} /$ day; $\mathrm{FBG}>160$ $\mathrm{mg} / \mathrm{dl}$, add $8 \mathrm{IU} /$ day).

Self-monitoring of glucoses by individuals with T2DM is essential since the initial basal dose is seldom sufficient to meet target glycemic goals and must be adjusted frequently by healthcare providers. For appropriate patients, empirical data suggest titration is equally effective whether guided by healthcare providers or by patients who are instructed in self-titration and who are safe to follow guidelines for titration based upon their health providers' instructions [19].

\section{Step 2:}

Add Rapid-acting Analog before Largest Meal. When OADs and basal long-acting insulin alone fail to achieve target glycemic goals, more intensive therapy that focuses on prandial control with rapidacting insulin is then added to the therapeutic regimen $[19,20]$. Of course, rapid-acting analogs blunt post-prandial glucoses. The ADA/ EASD also suggest adding mealtime rapid-acting insulin to basal insulin after 3 to 6 months when 2 hr. post-prandial glucoses are $>180$ $\mathrm{mg} / \mathrm{dl}$ and HbA1Cs are still elevated, even if fasting glucose goals are achieved [28]. 
While many individuals will resist going from injecting insulin once daily to injecting insulin four or more times daily, many will accept a two injection program as an initial step in multiple daily injections. For those patients who have a fairly consistent food intake pattern, it is better to keep basal insulin once daily and add a rapid acting insulin injection (i.e., bolus) prior to the largest meal of the day $[19,20]$.

Recommended initial dose of prandial rapid-acting insulin doses is 4 (29) to 5 units per meal (or about $10 \%$ of daily basal insulin dose) [19]. Using fixed titration, dosages of the rapid-acting analog can be increased every 2 to 3 days by 2 to 3 IU until target goal is reached, based upon the 2-hour postprandial glucose and taking into account the premeal glucose $[19,29]$. In contrast, using preprandial glucoses to adjust rapid-acting analogs, Bretzel [27] recommends adding 2 IU before the main meal if the glucose is $>150 \mathrm{mg} / \mathrm{dl}$ to $\leq 185 \mathrm{mg} / \mathrm{dl}$ and 3 IU before the main meal if the glucose is $>185 \mathrm{mg} / \mathrm{dl}$. Using postprandial glucoses to adjust rapid-acting analogs, 1 IU of a rapidacting analog is given before the main meal for glucoses $>135 \mathrm{mg} / \mathrm{dl}$ to $\leq 185 \mathrm{mg} / \mathrm{dl}$ and $2 \mathrm{IU}$ are added before the main meal for glucoses $>185 \mathrm{mg} / \mathrm{dl}$ [27].

\section{Step 3:}

Add Rapid-acting Analog before Two or More Meals. With individuals with T2DM who have inconsistent mealtimes, varying carbohydrates at mealtimes, and are not achieving target glucoses with basal insulin and one injection of rapid-acting insulin at the largest meal of the day after 3 to 6 months, a treatment regimen using basal insulin in conjunction with rapid-acting insulin prior to each meal is recommended [19]. However, current data is less clear regarding whether there are distinct differences in therapeutic glucoses when administering rapid-acting insulin with every meal versus using a stepwise approach to first add rapid-acting insulin to the largest meal of the day and then to other meals, if needed, based on pattern glucoses [30].

Initial recommended total daily doses of insulin are between 0.3 to 0.5 units $/ \mathrm{kg}$, with $50 \%$ of the total daily dose from a basal insulin analog and 50\% from a rapid-acting prandial analog [19]. In titrating total daily doses of basal insulin, Garber [19] again recommends increasing by $2 \mathrm{U}$ very $2-3$ days until target glucoses are achieved. With adjustable titration, the total daily dosage of basal insulin may be increased every 2 - 3 days based on the FBG (100-139 mg/dl, add $1 \mathrm{U}$; FBG 140-180 mg/dl, add 2 U; FBG > $180 \mathrm{mg} / \mathrm{dl}$, add 4 U) [19].

With fixed titration of rapid-acting analogs, the prandial dosage may be increased by $10 \%$ for any meal if 2 hour post-prandial and subsequent pre-meal glucoses are $>180 \mathrm{mg} / \mathrm{dl}$ [19]. Alternately, adjustable titration of rapid-acting insulin may be used, with mealtime bolus insulin dosages of 1-2 units of rapid acting insulin for each 15-20 gram carbohydrates [31].

\section{Implications for Nurses}

Health professionals face a variety of health clinician, health system, and patient barriers in initiating and titrating insulin therapy in T2DM. Interventions for these barriers overlap, with interventions being applicable to more than one barrier. In addressing health clinician barriers, bidirectional patient and health team communication is an essential component of glycemic control in monitoring patients intensively when initiating and titrating insulin therapy [16]. To illustrate, one cluster-randomized, multicenter trial of 483 participants examined the impact of structured self-monitoring of blood glucose (SMBG) on physician treatment modification recommendations and glycemic outcomes for patients with T2DM over 12 months. Primary care practices reviewed SMBG results quarterly, using patient-graphed seven-point glucose profiles over 3 consecutive days. Physicians also received a treatment algorithm based on SMBG patterns. Of patients who received at least one treatment modification, structured SMBG patients had greater reductions in $\mathrm{HbA1C}$ than usual care patients $(-1.2 \%$ vs. $-0.8 \%, \mathrm{P}<0.03)$.

These findings suggest collaborative use of structured SMBG data leads to earlier, more frequent, and more effective treatment modification for individuals with poorly controlled T2DM. Written and schematic evidence of SMBG results given to health providers by patients also appears to be a useful strategy to improve target glucose levels [32].

Treatment algorithms for initiating and titrating insulin also are potentially useful for addressing HbAlC serum lab values that are above target glucose goals. For example, one prospective, parallelgroup, randomized, controlled clinical trial enrolled 300 critically ill patients from a single tertiary referral center and compared expert nurse-directed glycemic control with a computerized algorithmguided glycemic control, which was designed to assist nurses in titrating insulin to achieve tight glucose control (i.e., $80-110 \mathrm{mg} / \mathrm{dl}$ ). Compared with expert nurses, the computerized algorithm-guided glycemic control improved efficacy of tight glucose control without increasing the rate of hypoglycemia [33].

Another 24-week, randomized, parallel-group, four-arm, open-label study of 7,893 adults with type 2 diabetes who were uncontrolled by oral antidiabetic agents and required insulin, compared four methods for titrating basal glargine insulin: 1) usual (no unsolicited contact between visits) insulin titration using a simple algorithm with laboratory HbA1C testing, 2) usual titration with point of contact HbA1C testing, 3) active (weekly monitored) titration with laboratory $\mathrm{HbA1C}$ testing, or 4) active titration with point of care HbA1C testing. The addition of insulin glargine using a simple algorithm achieved significant improvements in glycemic control in patients with type 2 diabetes. Active weekly titration resulted in significant incremental improvements in glycemic control. Among patients receiving active titration, point of contact $\mathrm{HbA1C}$ testing resulted in a greater portion achieving $\mathrm{HbA} 1 \mathrm{C}<7.0 \%$ [34]. These findings suggest the importance of active titration with consistent follow-up by health providers who routinely order and discuss $\mathrm{HbA1C}$ results and implications with their patients during clinic/office visits.

Education also is a key component of T2DM treatment programs [20]. As such, nurses provide information about diabetes selfmanagement behaviors, including eating a healthy diet, participating in consistent exercise, monitoring blood glucose levels, taking medications such as insulin, understanding emotional aspects of living with diabetes, using problem-solving skills to manage diabetes-related self-care problems, and decreasing risks of associated complications [35]. In addressing the barrier related to the amount of time required to sufficiently educate patients and families about insulin therapy and diabetes self-management skills, adjunct methods to deliver information are appropriate. For example, adjunct methods to deliver information about T2DM, such as telephone health lines, telemedicine, web-based models (available in libraries and churches), written information, and audio- and video-tapes are useful [36]. Checklists that highlight actual patient participation in diabetes selfmanagement skills also may be valuable in identifying skills and goals that are important to discuss during health provider visits. 
Because health clinician typically see a large volume of patients daily in a short time frame, clear, measurable goals that are mutually agreed upon by patients and their families at each routine visit are important in achieving target goals regarding diabetes selfmanagement behaviors. For example, establishing two to three shortterm, measurable self-management behaviors for patients to work toward before the next health provider contact may be useful. Also encourage patients and their families to meet these target goals by discussing them in each subsequent visit. Empirical research also indicates the importance of relating clinical measurements such as FBG and HbA1C to patients' symptoms and likely outcomes [37]. Hence, the meaning of serum lab values (e.g., $\mathrm{HbA1C}$ and corresponding serum glucose levels) regarding the risk of potential complications should also be addressed.

In addition to using adjunct methods to educate individuals with T2DM about their disease, health providers may address the health system barrier of brief office visits and inadequate interfaces with individuals with T2DM by using prerecorded telephone calls to patients about pattern glucoses, using an automated health education or nurse telephone follow-up based on individuals' responses during phone interactions also have been used successfully [38]. Community healthy advisors may be valuable offering useful strategies for adapting lifestyles to living with T2DM [36].

Effective patient-health care team communication also is the cornerstone to patient adherence and lessening feelings of personal failure in not implementing healthier behaviors that would prevent the need for insulin [16]. Initially, patients should be informed at the time of diagnosis that diabetes is a chronic and progressive disease and that the need for additional agents (including insulin) to control this chronic disease is normal [21]. Nurses play an important role in fighting the diabetes pandemic by participating in health promotion aimed at keeping individuals healthy [39]. In fact, Levich [39] reported that the central role of nurses in diabetes care involves improving health behaviors. Weight loss, healthy eating, and aerobic exercise are important health behavior strategies toward improving glycemic control and controlling weight in those with T2DM $[19,40]$. Healthcare professionals should individualize a plan of care for each patient to increase ensure adherence to weight loss, healthy eating based on the patients culture and lifestyle, and an exercise program aimed at keeping the individual healthy [13].

Telemedicine also has been used successfully in promoting weight loss $[41,42]$, using health coaches to promote healthy behaviors of 6718 individuals with T2DM. Health coaches had various backgrounds and at least a bachelor's degree with backgrounds such as nursing, psychology, social work, exercise physiology, nutrition education, and health education. Using an average of eight phone contacts, health coaches facilitated collaboration, relationship-building, active listening, goal setting, and questioning with participants to address their own personal agendas regarding lifestyle behaviors. Investigators reported significant improvement in healthy eating, exercise, and physical and emotional health, suggesting phone health coaching may be useful in improving diabetes self-management.

Health providers must assess patient characteristics (e.g., dexterity, vision) and lifestyles in selecting the most appropriate method for delivering insulin. Positive encouragement can lessen the fear of taking insulin injections. In fact, encouragement and education by clinicians such as nurses and other health providers typically will lower the resistance to using insulin therapy [20]. In fact, empirical data from a survey of 1400 insulin-naïve patients showed that less than $20 \%$ of patients were truly unwilling to start insulin therapy [43]. Further, future studies examining systems-level interventions to improve patient-provider communication about insulin are essential [44].

The fear of consequences of taking insulin, such as hypoglycemia and weight gain can be a significant barrier. The frequency of low glucoses is greater with more intensive glucose targets, exercise, delayed meals, alcohol consumption, sulfonylurea agents, renal dysfunction, diabetes duration, and memory impairment [15]. Encourage daily testing, randomizing pre- and postprandial glucoses. Analog insulins, pens, pumps, and finer needles lessen the chance of complications such as hypoglycemia and weight gain. Daily exercise also lessens the chance of weight gain.

Insulin pump therapy that requires fewer injections and insulin pen delivery devices patients can carry with them allows patients with T2DM the ability to integrate insulin therapy into their daily lives, lessening the barrier of insulin regimens. In fact, patients should be counseled that they can actually take control of their diabetes by using insulin therapy. As such, health providers should use motivational interviewing, support, and frequent words of encouragement to focus on positive aspects of insulin therapy in achieving target glucose levels [13].

\section{Conclusion}

T2DM is a challenging disease process for individuals and their family, especially with insulin therapy. Initiating and titrating insulin therapy is a continual process that involves health professionals working together to assess individuals with T2DM, establishing target glucose goals based upon patient characteristics, and using strategies to address heath clinician, health system, and patient barriers. Health professionals can better understand these barriers to assist individuals with T2DM to embrace insulin therapy. Treatment algorithms or tables are useful in assisting health professionals such as nurses to work as a team in initiating and titrating insulin therapy to achieve tighter target glucose levels. Health providers assess glycosylated hemoglobin laboratory values and other factors (e.g., patient characteristics) to select an appropriate insulin regimen, which may include basal insulin only or basal insulin plus a fast-acting prandial analog at one or more meals. Collectively, an understanding of these barriers and treatment regimens by health professionals can assist those with T2DM to achieve target glucoses and improve their quality of life.

\section{References}

1. U.S. Department of Health and Human Services, Centers for Disease Control and Prevention (2011) National diabetes fact sheet: National estimates and general information on diabetes and prediabetes in the United States

2. American Diabetes Association (2013) ADA clinical practice recommendations 2013: 2013 update. Diabetes Care 36: S1-S110.

3. Stark Casagrande S, Fradkin JE, Saydah SH, Rust KF, Cowie CC (2013) The prevalence of meeting A1C, blood pressure, and LDL goals among people with diabetes, 1988-2010. Diabetes Care 36: 2271-2279.

4. Peyrot M, Rubin RR, Khunti K (2010) Addressing barriers to initiation of insulin in patients with type 2 diabetes. Prim Care Diabetes 4 Suppl 1: S11-18.

5. Williamson C, Glauser TA, Burton BS, Schneider D, Dubois AM, et al (2014) Health care provider management of patients with type 2 diabetes mellitus: Analysis of trends in attitudes and practices. Postgraduate Medicine 126:145-160. 
6. Kruse RL, Olsberg JE, Shigaki CL, Parker Oliver DR, Vetter-Smith MJ, et al. (2013) Communication during patient-provider encounters regarding diabetes self-management. Family Medicine 45: 475-483.

7. Philis-Tsimikas A (2013) Initiating basal insulin therapy in type 2 diabetes: practical steps to optimize glycemic control. American Journal of Medicine 126(9 Suppl 1):S21-S27.

8. Brod M, Alolga SL, Meneghini L (2014 June 24) Barriers to initiating insulin in type 2 diabetes patients: Development of a new patient education tool to address myths, misconceptions and clinical realities. Patient

9. Ross SA (2013) Breaking down patient and physician barriers to optimize glycemic control in type 2 diabetes. Am J Med 126: S38-48.

10. Jones L, Crabb S, Turnbull D, Oxlad M (2014) Barriers and facilitators to effective type 2 diabetes management in a rural context: A qualitative study with diabetic patients and health professionals. Journal of Health Psychology 19: 441-453.

11. Kruse RL, Olsberg JE, Oliver DP, Shigaki CL, Vetter-Smith MJ, LeMaster JW. (2013) Patient-provider communication about diabetes self-care activities. Family Medicine 45: 319-322.

12. Lau AN, Tang $\mathrm{T}$, Halapy H, Thorpe $\mathrm{K}, \mathrm{Yu} \mathrm{CH}$ (2012) Initiating insulin in patients with type 2 diabetes. CMAJ 184: 767-776.

13. Petznick AM (2013) Identifying and addressing barriers to insulin acceptance and adherence in patients with type 2 diabetes mellitus. J Am Osteopath Assoc 113: S6-16.

14. Tanenberg R (2009) Insulin for type 2 diabetes: Who, when, and why?

15. Moghissi E, Ismail-Beigi F, Devine RC (2013) Hypoglycemia: minimizing its impact in type 2 diabetes. Endocr Pract 19: 526-535.

16. Unger J (2011) Insulin initiation and intensification in patients with T2DM for the primary care physician. Diabetes Metab Syndr Obes 4: 253-261.

17. Brod M, Christensen T, Thomsen TL, Bushnell DM (2011) The impact of non-severe hypoglycemic events on work productivity and diabetes management. Value Health 14: 665-671.

18. Brod M, Christensen T, Bushnell DM (2012) Impact of nocturnal hypoglycemic events on diabetes management, sleep quality, and nextday function: results from a four-country survey. J Med Econ 15: 77-86.

19. Garber AJ, Abrahamson MJ, Barzilay JI, Blonde L, Bloomgarden ZT, et al. (2013) American Association of Clinical Endocrinologistsâ $€^{\text {tm }}$ comprehensive diabetes management algorithm 2013 consensus statement. Endocrine Practice 19 (Suppl 2): 1-48

20. Inzucchi SE, Bergenstal RM, Buse JB, Diamant M, Ferrannini E, et al. (2012) Management of hyperglycaemia in type 2 diabetes: a patientcentered approach. Position statement of the American Diabetes Association (ADA) and the European Association for the Study of Diabetes (EASD). Diabetologia 55: 1577-1596.

21. Bailey $\mathrm{T}$ (2013) Options for combination therapy in type 2 diabetes: comparison of the ADA/EASD position statement and AACE/ACE algorithm. Am J Med 126: S10-20.

22. Canadian Diabetes Association Clinical Practice Guidelines Expert Committee (2013) Clinical practice guidelines: Pharmacologic management of Type 2 diabetes. Canadian Journal of Diabetes 37:S61S68.

23. Powers AC, Dâ $€^{\text {ma }}$ Alessio D (2011) Endocrine pancreas and pharmacotherapy of diabetes mellitus and hypoglycemia. In L Brunton (Ed) AC Powers \& D Dâ $€^{\mathrm{m}}$ Alessio, The pharmacological basis of therapeutics (12th ed., pp. 1248-1269), McGraw-Hill.

24. Chan PF, Lai LK, Wong SN, Chao DV, Lau IT (2013) Review on the use of insulin in primary care. Hong Kong Med J 19: 52-60.

25. Holman RR, Farmer AJ, Davies MJ, Levy JC, Darbyshire JL, et al. (2009) Three-year efficacy of complex insulin regimens in type 2 diabetes. $\mathrm{N}$ Engl J Med 361: 1736-1747.

26. Swinnen SG, Simon AC, Holleman F, Hoekstra JB, Devries JH (2011) Insulin detemir versus insulin glargine for type 2 diabetes mellitus. Cochrane Database Syst Rev : CD006383.
27. Bretzel RG, Eckhard M, Landgraf W, Owens DR, Linn T (2009) Initiating insulin therapy in type 2 diabetic patients failing on oral hypoglycemic agents: basal or prandial insulin? The APOLLO trial and beyond. Diabetes Care 32: S260-S265.

28. Wolffenbuttel BH, Klaff LJ, Bhushan R, Fahrbach JL, Jiang H, et al. (2009) Initiating insulin therapy in elderly patients with Type 2 diabetes: Efficacy and safety of lispro mix 25 vs. basal insulin combined with oral glucose-lowering agents. Diabetes Medicine 26:1147â €“1155.

29. Nathan DM, Buse JB, Davidson MB, Ferrannini E, Holman RR, et al. (2009) Medical management of hyperglycemia in type 2 diabetes: A consensus algorithm for the initiation and adjustment of therapy: a consensus statement of the American Diabetes Association and the European Association for the Study of Diabetes. Diabetes Care 32: 193-203.

30. Rodbard HW, Visco VE, Andersen H, Hiort LC, Shu DH. (2014) Treatment intensification with stepwise addition of prandial insulin aspart boluses compared with full basal-bolus therapy (FullSTEP Study): A randomised, treat-to-target clinical trial. Lancet, Diabetes \& Endocrinology 2: 30-37.

31. Leahy JL1 (2012) Insulin therapy in type 2 diabetes mellitus. Endocrinol Metab Clin North Am 41: 119-144.

32. Polonsky WH, Fisher L, Schikman CH, Hinnen DA, Parkin CG, et al. (2011) A structured self-monitoring of blood glucose approach in type 2 diabetes encourages more frequent, intensive, and effective physician interventions: results from the STeP study. Diabetes Technology \& Therapeutics 13: 797-802.

33. Van Herpe T, Mesotten D, Wouters PJ, Herbots J, Voets E, et al. (2013) LOGIC-insulin algorithm-guided versus nurse-directed blood glucose control during critical illness: The LOGIC-1 single-center, randomized, controlled clinical trial. Diabetes Care 36:188-94.

34. Kennedy L, Herman WH, Strange P, Harris A; GOAL AIC Team (2006) Impact of active versus usual algorithmic titration of basal insulin and point-of-care versus laboratory measurement of $\mathrm{HbAlc}$ on glycemic control in patients with type 2 diabetes: The Glycemic Optimization with Algorithms and Labs at Point of Care (GOAL A1C) trial. Diabetes Care 29:1-8.

35. Haas L, Maryniuk M, Beck J, Cox CE, Duker P, et al. (2013) National standards for diabetes self-management education and support. Diabetes Care 36 Suppl 1: S100-108.

36. Massey CN, Appel SJ, Buchanan KL, Cherrington AL (2010) Improving diabetes care in rural communiites: An overview of current initiatives and a call for renewed efforts. Clinical Diabetes 28: 20-27.

37. Kruse RL, Olsberg JE, Shigaki CL, Parker Oliver DR, Vetter-Smith MJ, et al. (2013) Communication during patient-provider encounters regarding diabetes self-management. Fam Med 45: 475-483.

38. Schillinger D, Handley M, Wang F, Hammer H (2009) Effects of selfmanagement support on structure, process, and outcomes among vulnerable patients with diabetes: A three-arm practical clinical trial. Diabetes Care 32: 559-566.

39. Levich BR (2011) Diabetes management: optimizing roles for nurses in insulin initiation. J Multidiscip Healthc 4: 15-24.

40. Marrero DG, Ard J, Delamater AM, Peragallo-Dittko V, Mayer-Davis EJ, et al. (2013) Twenty-first century behavioral medicine: A context for empowering clinicians and patients with diabetes. Diabetes Care 36: 463-470.

41. Ahrendt AD, Kattelmann KK, Rector TS, Maddox DA (2014) The effectiveness of telemedicine for weight management in the MOVE! Program. J Rural Health 30: 113-119.

42. Lawson KL, Jonk Y, O'Connor H, Riise KS, Eisenberg DM, et al. (2013) The impact of Telephonic Health Coaching on Health Outcomes in a High-risk Population. Glob Adv Health Med 2: 40-47.

43. Polonsky WH, Hajos TR, Dain MP, Snoek FJ (2011) Are patients with type 2 diabetes reluctant to start insulin therapy? An examination of the scope and underpinnings of psychological insulin resistance in a large, international population. Current Medical Research and Opinion 27:1169-1174. 
Citation: Grant JS, Hess A, Steadman LA (2015) Overview of Common Regimens Used for Initiating and Titrating Insulin in Individuals with Type 2 Diabetes Mellitus. J Nurs Care 4: 226. doi:10.4172/2167-1168.1000226

Page 9 of 9

44. Ratanawongsa N, Crosson JC, Schillinger D, Karter AJ, Saha CK et al. (2012) Getting under the skin of clinical inertia in insulin initiation: The
Translating Research Into Action for Diabetes (TRIAD) Insulin Starts Project. Diabetes Educator 38: 94-100. 